\title{
WIEŚS POLESKA DOBY PRZEMIAN LAT TRZYDZIESTYCH XX WIEKU W UJĘCIU JÓZEFA OBRĘBSKIEGO
}

\author{
THE VILLAGE IN POLESIE: \\ TRANSFORMATIONS OF THE 1930s \\ IN THE VIEW OF JÓZEF OBRĘBSKI
}

\begin{abstract}
The article deals with political and social themes of Józef Obrębski's texts, which were written in the second half of the 1930s and were devoted to Polesie. Obrębski made his ethnosociological research in 1934-1937. It was the last phase of the great depression. Obrębski noted changes in political consciousness of inhabitants of the Polesie village. He described the consequences of the implementation of Polish-language education. He perceived the role and nature of communist influence. He wrote very critically about the attitude and role of local administration representatives. He did not limit himself to listing these problems. Instead, he tried to formulate proposals for activities that would have changed the attitude of inhabitants of Polesie voievodship towards the Polish State.
\end{abstract}

Key words: Polesie; Second Republic of Poland; great depression; political radicalism

\section{Streszczenie}

Artykut jest poświęcony polityczno-społecznym wątkom tekstów Józefa Obrębskiego, które powstały w drugiej połowie lat trzydziestych i odnoszą się do Polesia. Obrębski prowadzit swoje badania etnosocjologiczne w latach 1934-1937. Była to

\section{JÓZEF OBRĘBSKI \\ ETNOSOCJOLOGIA \\ POLESIE WCZORAJ I DZIŚ}

PIOTR CICHORACK

Uniwersytet Wrocławski, Wrocław

E-mail: cichoracki@op.p http://orcid.org/0000-0003-2523-2679

CITATION: Cichoracki, P. (2019). Wieś poleska doby przemian lat trzydziestych XX wieku w ujęciu Józefa Obrębskiego. Sprawy Narodowościowe. Seria nowa, 2019(51).

https://doi.org/10.11649/sn.1866

This work was supported by the author's own resources. No competing interests have been declared.

This is an Open Access article distributed under the terms of the Creative Commons Attribution 3.0 PL License (creativecommons.org/licenses/by/3.0/pl/), which permits redistribution, commercial and non-commercial, provided that the article is properly cited. (C) The Author(s) 2019

Publisher: Institute of Slavic Studies, Polish Academy of Sciences 
ostatnia faza wielkiego kryzysu. Odnotował przemiany świadomości politycznej mieszkańców poleskiej wsi. Opisywał konsekwencje implementacji polskojęzycznej oświaty. Dostrzegat rolę i charakter wpływów komunistycznych. Bardzo krytycznie wypowiadał się o postawie i roli przedstawicieli lokalnej administracji. Nie ograniczał się do rejestracji tych zjawisk. Próbował formułować propozycje działań, które zmieniłyby stosunek ludności Polesia do państwa polskiego.

Stowa kluczowe: Polesie; II Rzeczpospolita; wielki kryzys; radykalizm polityczny

W ojewództwo poleskie było tym obszarem w II Rzeczypospolitej, gdzie proces identyfikacji dominującej części ludności z państwem polskim napotykał liczne i różnorodne przeszkody. Przyczyny tego stanu rzeczy miały różnoraki charakter. Czynnikiem kluczowym, choć przecież teoretycznie nieprzesądzającym, był fakt, że wśród mieszkańców Polesia dominowała niepolska, wiejska ludność prawosławna. W realiach, jakie jednak stwarzała polityka narodowościowa władz państwowych, faktyczny status mniejszości narodowych czynił takie grupy upośledzonymi. Uwaga ta odnosi się do całego okresu międzywojennego. Zapóźnienie cywilizacyjne tego wiejskiego regionu mogło zostać pokonane jedynie poprzez olbrzymie inwestycje w infrastrukture komunikacyjną, gospodarczą i kulturową. Okazało się ono wyzwaniem niepokonywalnym w perspektywie dwóch dekad niepodległości. Nie zmienia to jednak faktu, że owa niemożność nie tylko nie sprzyjała integracji z państwem, ale zwiększała dystans odczuwany w stosunku doń przez ludność. W II RP nie zlikwidowano również pierwotnego konfliktu klasowego pomiędzy "dworem i wsią", tradycyjnie istniejącego na poleskiej wsi. Doświadczenie rewolucji rosyjskiej, w wypadku wiejskiej ludności Polesia często znane z uchodźczej autopsji, uzupełniało katalog podstawowych przyczyn istnienia wśród niej postaw - niekiedy radykalnie - kontestujących istniejący porządek prawny, polityczny i społeczny.

W sposób zorganizowany ów radykalizm wyrażał się dwojako. Zwłaszcza w latach dwudziestych objawiał się popieraniem legalnych lewicowych ugrupowań polskich, białoruskich i ukraińskich. Te możliwości skończyły się wraz ze zmonopolizowaniem miejscowego, zinstytucjonalizowanego życia politycznego i społecznego przez obóz sanacyjny, co nastąpiło na początku dekady lat trzydziestych. Inną emanacją było oparcie okazywane na wsi ruchowi komunistycznemu. Jego znaczenie w życiu poleskiej wsi nie polegało na liczbie jego „zarejestrowanych" uczestników. W swym apogeum, w połowie lat dwudziestych osiągnęła ona maksymalnie wartość około 1500 ludzi. Przez większą część okresu międzywojennego grupa członków organizacji komunistycznych oscylowała na Polesiu wokół kilkuset osób¹. Istotniejsza była popularność - niekiedy oddolnie przekształcanych - haseł i siła prosowieckich sympatii. Wieś poleska stała się bazą dla czynnych wystąpień przeciwko ładowi wewnętrznemu, a faktycznie przeciw państwu polskiemu. Do takich incydentów doszło w trzech okresach. Po raz pierwszy zaistniały one w I połowie lat dwudziestych, kiedy po zakończeniu wojny polsko-sowieckiej na obszarze województw północno-wschodnich pojawiły się nielegalne grupy zbrojne różnej proweniencji, działające z pomocą części chłopstwa. Polesie okazało się tym województwem, na terenie którego podobne działania były najintensywniejsze. W okresie kryzysu gospodarczego I połowy lat trzydziestych jedynie tutaj doszło do, zorganizowanych oddolnie, otwartych wystąpień

\section{.....}

1 Dane szczegółowe w: Cichoracki, 2016, ss. 38-42. 
zbrojnych. Jakkolwiek nieliczne i epizodyczne, ponownie wyróżniły one Polesie na tle pozostałych terenów w pasie od Wilna po Łuck. Polesie stało się wreszcie we wrześniu 1939 roku miejscem najbardziej brutalnego zwarcia jego niepolskich mieszkańców i instytucji reprezentujących upadającą II RP (Wierzbicki, 2000, ss. 91-105). W podobne przedsięwzięcia bezpośrednio zaangażowane było oczywiście niewiele osób. W realiach stabilnej państwowości obarczone ryzykiem, przyciągały one jedynie margines, jeśli wyrazić go liczbami bezwzględnymi. Ważniejsze wydaje się to, że hasła czy koncepcje oznaczające w praktyce wywrócenie istniejącego porządku społecznego i politycznego znajdowały na poleskiej wsi dość szeroki odbiór, będąc jednocześnie osadzane w kontekście miejscowych tradycji i wyobrażeń.

Prace socjologiczno-etnograficzne Józefa Obrębskiego poświęcone Polesiu należy dziś uznać za najpełniejszy obraz tamtejszej wsi w okresie międzywojennym². Odnosi się to również do nastrojów społecznych i politycznych. Obrębski uchwycił ich stan w momencie trudnym dla mieszkańców. Prowadził badania terenowe w latach 1934-1937, a więc w końcowej fazie tzw. wielkiego kryzysu gospodarczego i pierwszych lat poprawy koniunktury ekonomicznej. Siłą rzeczy postawy niezadowolenia, niepokoju, oczekiwanie zmiany, musiały silnie zaistnieć i nie mogły umknąć obserwatorowi tej klasy. Obrębski nie ograniczał się jedynie od odtworzenia istniejącego stanu rzeczy i wskazania jego przyczyn. Starał się przyjąć optykę chłopską, przy czym lektura jego prac nie pozwala na przesądzenie, jak dalece się z nią sam identyfikował. Deklarował, że nie czuje się powołany do "wyciągania wniosków praktyczno-politycznych" (Obrębski, 2007, s. 331). Już współcześni dostrzegali jednak, że jego badania poleskie mają na celu nie tylko odtworzenie istniejącego stanu rzeczy, ale stanowią przynajmniej punkt wyjścia mający "ułatwić polityce wypracowanie [...] recepty" (Obrębski, 2007, s. 320).

Na zakończenie uwag wstępnych należy poczynić jeszcze jedno spostrzeżenie. Obrębski pracował w większej mierze we wschodniej części województwa poleskiego (powiaty łuniniecki, stoliński, sarneński [od 1931 r. w województwie wołyńskim]) (Obrębski, 2007 [wkładka]). To o tyle istotne, że był to obszar mniej kłopotliwy jeśli idzie o nastroje społeczne z punktu widzenia administracji. Zorganizowany ruch komunistyczny był tu znacząco słabszy aniżeli w powiatach środkowych i zachodnich Polesia. Obrębski zdawał sobie sprawe z tego podziału i jego konsekwencji dla opisywanych przezeń postaw mieszkańców poleskiej wsi (Obrębski, 2007, s. 501).

Niektóre konstatacje Obrębskiego dotyczące procesów społecznych nie są przezeń bezpośrednio wiązane z problemem postaw kontestujących na poleskiej wsi. Wydają się jednak stanowić ważny element tła tych ostatnich. Do takich zaliczyć można zjawisko, które Obrębski określa generalnie jako „rozpad poleskiej grupy etnicznej”, dokonujący się w różnych sferach i na różnych poziomach (Obrębski, 2007, ss. 281-283). Dostrzega wpływ myślenia mitycznego i istnienia chłopskich „psychoz”, co jednak nie skłania go do negatywnego wartościowania owych zjawisk (Obrębski, 2007, s. 303). Istotne wydają się bowiem przede wszystkim skutki w postaci takiego a nie innego stosunku do państwa i istniejących relacji społecznych. Jedną z emanacji "rozpadu” była w ujęciu Obrębskiego rewizja relacji z państwem. Tradycyjnie było ono postrzegane jako element „naturalnego porządku świata”, gdzie „władza i lud spełniają swoje zasadniczo różne zadania” w relacji „pana i sługi” (Obrębski, 2007, ss. 287-288, 308). Bierny, całkowicie lojalny wobec

\section{- ...}

W trakcie pracy nad tekstem korzystano z najnowszej, jednotomowej edycji poleskich prac Obrębskiego. Zawiera ona nie tylko pisma i fragmenty prac jego autorstwa, ale również zapis dyskusji wokół jednego z tekstów: „Dzisiejsi ludzie Polesia”, która odbyła się we wrześniu 1936 r. (Obrębski, 2007). 
władzy lud jest przez tę drugą brany w opiekę. A jednak Obrębski sugeruje, że źródłem rosnącej niechęci nie była sama w sobie konieczność spełniania obowiązków w stosunku do państwa, czy - z drugiej strony - wykonywanie przezeń swoich prerogatyw. W dyskusji nad własnymi ustaleniami zastrzegał wręcz, aby nie odmawiać mieszkańcom poleskiej wsi „poczucia lojalności obywatelskiej” (Obrębski, 2007, s. 330). Uznawać mieli oni zasadność egzekwowania podatków, czy nawet brutalności postępowania przedstawicieli administracji, o ile odpowiadało to chłopskiemu pojmowaniu sprawiedliwości. Stąd też akceptacja przemocy w wykonaniu policji, o ile była elementem walki z "kryminalistyką wiejską" (Obrębski, 2007, s. 297).

Bardzo ważnym katalizatorem sygnalizowanych wyżej zmian wydawało się Obrębskiemu doświadczenie uchodźcze (czy wojenne - jak w wypadku żołnierzy armii carskiej) znacznej części miejscowego chłopstwa i jego pobyt w Rosji od 1915 roku (Obrębski, 2007, ss. 329, 508). Największa grupa powracających w ramach repatriacji napłynęła w latach 1921-1922. Oznaczało to, że niegdysiejsi uchodźcy byli świadkami wybuchu i tryumfu rewolucji rosyjskiej w wariancie bolszewickim. W jego wyniku nastąpił na rosyjskiej wsi przewrót społeczny i całkowita likwidacja warstwy ziemiańskiej uważanej przez tamtejsze chłopstwo za opresyjną. Z punktu widzenia poleskiego chłopa, dla którego antagonizm dwór - wieś często stanowił oś codzienności i punkt odniesienia mitów i psychoz, scenariusz rosyjski mógł wydawać się atrakcyjny i wart zastosowania po powrocie z tułaczki. Warunki w tej sferze zastane bowiem na miejscu dalekie były od rewizji. Poczucie nieusatysfakcjonowania chłopstwa było więc czytelne, mimo że formalnie relacje społeczne nosity - co zauważał nie tylko Obrębski - zewnętrznie cechy demokratyczne, a i relacje „dwór - wieś" tradycyjnie nie były jednoznacznie antagonistyczne. Uwarunkowania zasadniczego konfliktu zmieniały się, ale on sam wciąż istniał i w ramach istniejącego porządku wydawał się nie do usunięcia (Obrębski, 2007, ss. 311-313, 329; Wysłouch, 2013, s. 32; Смалянчук, 2013, ss. 138-154).

Pobyt w Rosji szczególnie mocno oddziałał według Obrębskiego na młode pokolenie. Zdaje się to nie ulegać wątpliwości (Obrębski, 2007, s. 329; Бежанства 1915 года , 2000, s. 31; Ласкович \& Ласкович, 2002, s. 72). Niegdysiejsi „bieżeńcy” okazali się grupą bardziej zapalną ze względu na swój status materialny. Bardzo często wracali do gospodarstw zrujnowanych, leżących przez kilka lat odłogiem (Prymaka-Oniszk, 2016, ss. 259265). Z radykalizacją postaw korespondowała w tej grupie zmiana postrzegania Cerkwi prawosławnej oraz stosunek do religii jako takiej. Pojawił się silny prąd racjonalistycznowolnomyślicielski, a nawet demonstracyjne bezbożnictwo. Zachwianiu uległa siła tradycji i rytuału4.

Młodzież dążyła do „poprawienia swojego bytu i podniesienia swej roli społecznej” (Obrębski, 2007, s. 284). Tak wybrany punkt odniesienia i podobne dążenia rodziły frustrację, wynikającą z niemożności realizacji aspiracji wykształconych na drodze czy to pośredniej obserwacji świata pozapoleskiego, czy to bezpośrednich własnych z nim doświadczeń (Obrębski, 2007, s. 283, podobnie ss. 296, 299). W pierwszym wypadku mowa przede wszystkim o szkole, w drugim o służbie wojskowej. W ujęciu Obrębskiego aspirotwórcza rola szkoły polskiej jawi się wyjściowo jako paradoks. Jej program koncentrował się bowiem na realizacji zadań polonizacyjnych, nie zaś „tendencji i potrzeb kulturalnych chłopa poleskiego" (Obrębski, 2007, s. 348). Mimo to szkoła pozostawała dla niegdysiejszych ucz-

\section{- •.・}

Państwowe Archiwum Obwodu Brzeskiego, f. 1, o. 2, d. 2001, k. 1, „Ludność i repatriacja wg danych administracyjnych" [niedatowane].

4 Określenia w cudzysłowie za J. Obrębskim (Obrębski, 2007, ss. 486, 511). 
niów wspomnieniem pozytywnym, bo związanym z doznaniami odmiennymi od wiejskiej codzienności, która bardzo szybko pochłaniała ich po ukończeniu edukacji. Co istotne, ku ich żalowi, ponieważ „szkoła odkryła przed nim [uczniem] piękno i wspaniałość nowego świata" (Obrębski, 2007, s. 404). Nawet, jeśli jednak w zdecydowanej większości wypadków dla dzieci był to świat obcy, sprzeczny z pamięcią wsi, „pański”, właśnie ze względu na swoją pańskość zyskiwał na atrakcyjności. Choćby w swej specyficznej formule patriotyczno-militarnej edukacja kreśliła wizje drogi awansu społecznego „z chłopa na pana”. Inną kwestią pozostaje, że zdaniem Obrębskiego podobny efekt nie był celem polskiej szkoły na Polesiu, co z tej perspektywy oznaczało jej klęskę (Obrębski, 2007, s. 433).

Służba wojskowa odbywana była przez młodego Poleszuka najczęściej w zachodnich regionach państwa, a więc na terenach najbardziej zaawansowanych cywilizacyjnie, biegunowo pod tym względem usytuowanych w stosunku do Polesia. Stawała się ona według Obrębskiego „silnym bodźcem emocjonalnym zainteresowań szkolnych” (Obrębski, 2007, s. 354). Rezerwista powracający do siebie starał się wprowadzać poznane zwyczaje. Natykał się w tym momencie na opór starszego pokolenia, przede wszystkim jednak nie był w stanie wykorzystać pozyskanego kapitału kulturowego, wpychany ponownie do roli pogardzanego „mużyka” (Tołpa, 1936, ss. 109-110).

Co interesujące, u podłoża międzywojennego wiejskiego radykalizmu leżał, paradoksalnie, czynnik konserwatywny, mający swe źródło w konflikcie z „dworem” (Obrębski, 2007, s. 508). Było nim tradycyjne spojrzenie na polskość i Polaków, utożsamianych z opresyjną dla wsi pańskością (Obrębski, 2007, s. 289). Państwo polskie również stawało się tożsame z owym pojęciem, biorąc w obronę "pańskie” interesy i lekceważąc chłopskie dążenia wyrażające się zwłaszcza w postulacie objęcia władaniem ziemi. Dodajmy, aspiracje bardzo bliskie realizacji w okresie zamętu rewolucyjnego lat 1917-1920 (Obrębski, 2007, s. 291). Urzędnicy i funkcjonariusze państwowi, zwłaszcza niżsi, tacy jak szeregowi policjanci czy urzędnicy gminni i powiatowi, wreszcie nieeksponowani przez Obrębskiego sekwestratorzy, stawali się uosobieniem codziennego ucisku. Nawet gdyby przyjąć zastrzeżenia formułowane tu współcześnie pod adresem Obrębskiego, który miał jakoby uogólniać problem wadliwych zachowań urzędników (Obrębski, 2007, s. 320 [wypowiedź Juliusza Poniatowskiego]), to nie zmieniały one faktu powszechnej recepcji na wsi podobnych patologii. Tradycyjny antagonizm klasowy sprzęgnął się tym samym z nowoczesnym konfliktem politycznym i narodowym. Separowało to psychologicznie mieszkańców wsi od państwa i w konsekwencji radykalizowało niechętny doń stosunek (Obrębski, 2007, ss. 293, 298). Wnioski sprowadzające się do podniesienia „sprawiedliwości urzędów" wydawały się oczywiste niektórym odbiorcom badań Obrębskiego, wchodzących także w skład elity sanacyjnej (Obrębski, 2007, s. 320 [wypowiedź Juliusza Poniatowskiego], s. 323 [wypowiedź Mariana Wójcika], s. 324 [wypowiedź Bronisława Chamca]). Głosy wyrażające satysfakcję z pracy administracji należy uznać za odosobnione, choć zwraca uwage, że jeden z nich wyartykułował starosta 5 .

Istoty rzeczy nie zmieniały fluktuacja zewnętrznych, politycznych postaw chłopstwa. Masowo poparło ono legalne partie lewicowe w I połowie lat dwudziestych, czego dowodem był wynik wyborów parlamentarnych w 1922 roku6. Owo poparcie okazało się jednak

5 ,[...] sprawa władz administracyjnych. Błędy były w pierwszych latach niepodległości, teraz zaś jest bardzo dobrze" (Obrębski, 2007, s. 323 [wypowiedź Krzysztofa Brezy]); „Nie ma uprzedzeń do władzy [...]. Skończyły się czasy, kiedy na kresy posyłano za karę. Teraz posyła się misjonarzy, nie urzędników. Jest dobrze" (Obrębski, 2007, s. 325 [wypowiedź Czesława Zbierańskiego]).

6 Państwowe Archiwum Obwodu Brzeskiego, f. 67, o. 1, d. 264, k. 26, Sprawozdanie Poleskiego Urzędu Wojewódzkiego o stanie bezpieczeństwa publicznego za listopad 1922 r. z 13 I 1923 r. 
krótkotrwałe. Do połowy lat trzydziestych administracja zasadniczo ograniczyła możliwości ruchu komunistycznego. A jednak, podobnie jak Obrębski, rządzący województwem poleskim nie mieli wątpliwości, że nie jest to równoznaczne z przełamaniem nastrojów niechętnych polskiej państwowości (Obrębski, 2007, s. 308; Śleszyński, 2009).

Obrębski zasadnie dostrzegł rolę kryzysu gospodarczego I połowy lat trzydziestych jako zjawiska katalizującego nastroje społeczne i generującego postawy radykalne (Obrębski, 2007, ss. 292-293, 485, 487). Generalnie, w skali całego kraju, odbił się on zwłaszcza na poziomie życia wsi. Nie dziwi więc, że przyjął na rolniczym Polesiu ostrą formę i na pewno przyczynił się do wzrostu niezadowolenia. Takie zjawiska, jak gwałtowny spadek cen żywności, niemal całkowita likwidacja możliwości zarobkowania poza własnym gospodarstwem (eksploatacja lasów), początkowa sztywność systemu podatkowego, zaostrzenie - tradycyjnie trudnych - relacji ekonomicznych z dworem, wreszcie zablokowanie kanałów emigracji, oznaczały pauperyzację poleskiej wsi (Obrębski, 2007, ss. 490-493). W efekcie na terenie województwa znacznie pogorszył się stan bezpieczeństwa wewnętrznego, wzrosła przestępczość kryminalna (na tle nieprzestrzegania prawa własności) i - co tu kluczowe - polityczna. Dochodziło do otwartych wystąpień będących objawami buntu społecznego, niekiedy krwawych. Najwięcej tego typu incydentów miato miejsce w związku z egzekwowaniem zaległości podatkowych (Cichoracki, 2016, ss. 155-156). Towarzyszył temu wzrost wpływów nielegalnych organizacji komunistycznych.

„Program”, z którym identyfikowała się poleska wieś, Obrębski ujął następująco:

ustanowienie z decyzji lub za zgodą najwyższych władz państwowych nowego prawa, prawa ruskiego, białoruskiego czy ukraińskiego, którego treścią miała być nowa słoboda, słoboda polegająca na przywróceniu tradycyjnego systemu władania ziemią czy nawet ponownym uwłaszczeniu, oraz na udzieleniu przywilejów władczych chłopom i otwarciu im dostępu do godności publicznych i stanowisk państwowych (Obrębski, 2007, s. 302).

Jeśli miała być to zasadnicza recepta, której zastosowanie dawało szansę na związanie poleskiej wsi z państwem polskim, rodzi się pytanie, jak dalece była ona realna w warunkach II RP.

Ujęcie Obrębskiego dzieli się na dwie części. Pierwsza dotyczy stosunków własnościowych i pożądanej na wsi metody ich rewizji, czy też raczej przewrotu w tejże dziedzinie. Reformę rolną, mimo różnorakich przeszkód, przeprowadzano na Polesiu od początku lat dwudziestych. Jej intensywność była różna. Generalnie w latach trzydziestych, a więc także w okresie kiedy Obrębski prowadził swe poleskie badania, parcelacja zmniejszyła swoją dynamikę i na pewno nie zaspakajała głodu ziemi odczuwanego na wsi (Mały Rocznik Statystyczny 1938, 1938, s. 65; Mały Rocznik Statystyczny 1939, 1939, s. 70; „Plan parcelacyjny na Polesiu na rok 1939", 1938; Пущук, 2006, s. 40; Weinfeld, Szturm de Sztrem, \& Piekałkiewicz, 1925, s. 24). Jednak wydaje się, że kluczowym elementem rozumowania poleskiego chłopa w ujęciu Obrębskiego jest nie tyle sam fakt objęcia ziemi w swoje posiadanie, ile sposób, w jaki to powinno zostać dokonane. Kategoria "słobody" oznacza tu - jak się wydaje - radykalną, całkowitą eliminację większej własności ziemskiej, dokonanej na zasadach chłopskiej aksjologii, bez ponoszenia przez wieś kosztów materialnych77. Oznaczałoby to kompletne zanegowanie prawa własności, możliwe jedynie $w$ realiach rewolucji społecznej. Ta zaś była przecież wykluczona z punktu widzenia zasad ładu wewnętrznego, na których oparta była II RP.

7 Pojęcie związane było z okresem od 1915 r. do zakończenia wojny polsko-bolszewickiej, kiedy wieś w znacznym stopniu przestała odczuwać nacisk struktur państwowych (Mędrzecki, 2018, s. 342). 
Drugi fragment związany jest z zaspokajaniem indywidualnych aspiracji do aktywności politycznej, zwłaszcza chyba społecznej, a więc kwestii tylokrotnie podnoszonej i komentowanej przez Obrębskiego. Tutaj napięcie pomiędzy oczekiwaniami i teoretycznymi możliwościami ich realizacji wydawało się łatwiejsze do pokonania. Oczywiście sprawą dyskusyjną pozostaje, czy byłoby to możliwe na drodze decyzji politycznych, związanych na przykład z koncepcjami polityki narodowościowej, a jak dalece byłoby zależne od czynników bardziej obiektywnych, takich jak sytuacja ekonomiczna czy wyjątkowo niski stopień zaawansowania cywilizacyjnego regionu.

Pisma poleskie Obrębskiego zawierają również sugestie dotyczące rewizji codziennej praktyki stosunków na linii władza (administracja) - wieś. Niechęć do państwa byłaby zdaniem Obrębskiego słabsza, gdyby „normy i represje, stosowane przez grupę urzędniczą pokrywały się z tymi, które odpowiadają obyczajom społeczeństwa miejscowego" (Obrębski, 2007, s. 297). Pojawia się pytanie, jak należałoby przeformułować „codzienne” funkcjonowanie aparatu administracyjnego. Czy w tezie Obrębskiego kryje się postulat rewizji fundamentów, w postaci niekreowania przepisów dotyczących na przykład "higieny, bezpieczeństwa i porządku", czy też jedynie sugestia łagodniejszego ich egzekwowania? Druga interpretacja wydaje się zasadna, jeśli uwzględnić uwagę o sekwestracjach „brutalniejszych niż w innych stronach Polski" (Obrębski, 2007, s. 297)². Obrębski zauważa, że stosunek poleskiego chłopa do „polskiego prawa” nie był jednoznacznie wrogi (odrzucający). Problem zasadzał się w jego pojęciu na wadliwym (opresyjnym) stosowaniu go przez plejadę urzędników mających styczność z wsiąa . Taka węższa interpretacja nie wyczerpuje chyba jednak problemu. „Polskie prawo” jako takie wydawało się chłopu źródłem krzywdy (Obrębski, 2007, s. 314). Wydaje się więc, że jedynie jego unicestwienie (kompletna zmiana) da szansę na odmianę złego położenia.

Rozumowanie Obrębskiego nie było - pozornie - pozbawione pewnej dozy fatalizmu. Mniejsza tu o konstatowany przezeń tradycyjny kompleks niższości Poleszuka i adorację "obcych wzorów kulturalnych", trudnych czy niemożliwych do realizacji na miejscu (Obrębski, 2007, s. 473). Przywoływanie przezeń uniwersalnych mechanizmów społecznych prowadziło do wniosku, że poleska wieś skazana jest na radykalizm, bez względu na „otoczenie jej opieką i obdarowanie szeregiem dobrodziejstw cywilizacji i kultury" (Obrębski, 2007, s. 304) przez państwo. Owa „opieka” oferowana z pozycji wyższościowych budzić bowiem będzie zawsze, w miejsce odruchu wdzięczności, opór i bunt. Zawarta była tu jednak sugestia, że problemem jest nie tyle samo „cywilizowanie", ile czynienie go w duchu „aroganckiego kulturträgeryzmu” (Obrębski, 2007, ss. 312-313). Obrębski nie był w podobnych spostrzeżeniach osamotniony. Co interesujące, podobne konstatacje formułowano równocześnie w obrębie miejscowej administracji państwowej. Inną kwestią pozostaje, jak dalece świadomość najwyższych urzędników wojewódzkich miała przełożenie na codzienność kontaktów: szeregowi przedstawiciele państwa - poleski chłop. Nawet z perspektywy kluczowych przedstawicieli miejscowej administracji rzeczywistość napawała pesymizmem mimo ostrego, ale zapewne tylko werbalnego nacisku na podwładnych $^{10}$. Jak się wydaje, jednym ze źródeł problemu był paradoks. Polegał on na jednoczesnym żądaniu od urzędników podmiotowego traktowania chłopa, z drugiej jednak

\section{-....}

8 Metody wymuszania spłaty zaległości podatkowych w I połowie lat 30. stały się w przedmiotem debaty publicznej. Także różne działy administracji były z czasem świadome problemu i starały się uruchomić zmiany na tym polu (Strefowe Archiwum w Mołodecznie, f. 9, o. 1, d. 209, k. 88, Pismo starosty mołodeckiego z 4 IV 1934 r.; Landau \& Tomaszewski, 1982, ss. 217-218, 272-273).

9 „Funkcjonariusze objęci tą koncepcją: gajowi, policja, wójt, urzędnicy gminni, sąd grodzki, komisarz ziemski, biuro przepisywania na maszynie, poczta, starosta i urzędnicy starostwa" (Obrębski, 2007, s. 314).

10 PAOB, f. 1, o. 10, d. 1089, k. 1, Pismo wojewody poleskiego z 25 VI 1938 r. 
strony oczekiwaniu, że będą oni realizować na co dzień politykę polonizacyjną, całkowicie lekceważąc poczucie odrębności językowej i kulturowej mieszkańców wsi. Oczywiście istotną okoliczność stanowiło to, że stopniowo realizowano w aparacie państwowym zasadę ograniczania jego składu do Polaków - katolików (Mędrzecki, 2018, s. 381).

Obrębski zauważa, że w realiach lat trzydziestych poleska wieś pozbawiona była politycznego reprezentanta swoich aspiracji (Obrębski, 2007, s. 315). Oceniając dziś realność szans zmiany tego stanu rzeczy, trzeba zwrócić uwagę na teoretyczne możliwości w tym względzie w warunkach państwa rządzonego przez obóz sanacyjny. Wydają się one nikłe. Nic nie wskazuje na to, aby rządzący zgodzili się na funkcjonowanie jakiejkolwiek politycznej konkurencji, nawet jak na warunki "kresowe” wyjątkowo szybko i skutecznie na Polesiu wyeliminowanej do początku lat trzydziestych. Owa efektywność miała jednak swoje źródło nie tylko w zdecydowaniu miejscowej administracji. Można przypuszczać, że słabość politycznych alternatyw dla obozu rządzącego wynikała z zupełnego braku miejscowych niepolskich środowisk, które by mogły odegrać chociaż rolę wspótliderów takich ruchów. Wydaje się, że sytuacja nie zmieniła się pod tym względem także pod koniec lat trzydziestych. Zdaniem Obrębskiego, potencjalne procesy elitotwórcze były zahamowane poprzez formułe rządów "autorytatywno-policyjnych", które nie tylko nie dawały szansy na zrobienie jakiejkolwiek kariery w administracji, ale eliminowały chłopa nawet z samorządu gminnego, obsadzanego przez przybyszy - urzędników czy nauczycieli (Obrębski, 2007, s. 350). Zarzut ten nie wydaje się w pełni zasadny w świetle wyników wyborów przeprowadzonych w latach 1938-1939. W radach gminnych większość miejsc zajęli zapewne Poleszucy ${ }^{11}$. Można założyć, że sytuacja wyglądała dość podobnie w okresie badań terenowych Obrębskiego. Trudno natomiast przesądzić o skali udziału prawosławnych chłopów, jeśli chodzi o sprawowane stanowiska. Był on zapewne znacznie mniejszy aniżeli odsetek mandatów, a nie ulega wątpliwości, że te funkcje stanowiłyby najlepszą szkołę zaangażowania społecznego, a w przyszłości może i politycznego.

Obrębski był bardzo krytyczny wobec efektów pracy polskiej szkoły na Polesiu. W tej kwestii jego recepta na wyeliminowanie depresyjnych skutków oddziaływania systemu oświaty była wyartykułowana jednoznacznie. Należało wyeliminować „mało dostępny i wąski przełaz" dla awansu społecznego poprzez przeobrażenie szkoły w "narzędzie walki wyzwoleńczej chłopa - mużyka, uczące go pogardzać urokiem pańskim i wpajające weń chłopskie poczucie godności, świadomość własnych praw i wiarę we własne możliwości i własne siły w skali państwowej" (Obrębski, 2007, s. 434). Wydaje się, że podobna zmiana paradygmatu istotnie była pożądana, niemniej trudna od wyobrażenia inaczej aniżeli jako efekt głębokich zmian politycznych.

Także dziś obserwacje Obrębskiego dotyczące korzeni i kształtu poleskiego radykalizmu można uznać za bardzo wiarygodne. Współczesne badania historyczne, oparte na zupełnie innym warsztacie aniżeli wykorzystywany przezeń, skłaniają często do podobnych bądź tożsamych wniosków. Wydaje się jednak, że próbując wskazać metody rozładowania narastającego społecznego napięcia, Obrębski konstruował scenariusze nie zawsze realne. Jakkolwiek by jednak oceniać proponowane przezeń środki zaradcze, nie ulega wątpliwości, że zdiagnozowane problemy nie zostały rozwiązane. Przynajmniej w tej perspektywie, jaką stworzył wrzesień 1939 roku, będący w istocie najradykalniejszą z możliwych form

\footnotetext{
11 Archiwum Akt Nowych, Urząd Wojewódzki Poleski, sygn. 32, k. 28, Sprawozdanie sytuacyjne nr 4 za kwiecień z 10 V 1939 r.
} 
kryzysu państwa. O ile w ostatnich miesiącach przed wybuchem wojny i w pierwszych dwóch tygodniach jej trwania odruchy zewnętrznego niezadowolenia czy buntu społecznego zostały całkowicie wyeliminowane, o tyle po agresji sowieckiej Polesie okazało się tym spośród wschodnich regionów II RP, gdzie ostatnie zwarcie instytucji reprezentujących państwo polskie i jego niepolskich obywateli przyjęło najbrutalniejsze formy (Wierzbicki, 2000, ss. 91-105).

\section{ARCHIWALIA}

Archiwum Akt Nowych, Urząd Wojewódzki Poleski

Państwowe Archiwum Obwodu Brzeskiego, f. 1; f. 67

Strefowe Archiwum w Mołodecznie, f. 9

PRASA

"Dziennik Brzeski", 1938

\section{BIBLIOGRAFIA}

Cichoracki, P. (2016). Komuniści na Polesiu w latach 1921-1939. Łomianki: LTW.

Landau, Z., \& Tomaszewski, J. (1982). Gospodarka Polski międzywojennej: T. 3. 19301935. Warszawa: PWN.

Mały Rocznik Statystyczny 1938. (1938). Warszawa: Główny Urząd Statystyczny.

Mały Rocznik Statystyczny 1939. (1939). Warszawa: Główny Urząd Statystyczny.

Mędrzecki, W. (2018). Kresowy kalejdoskop: Wędrówki przez ziemie wschodnie Drugiej Rzeczypospolitej 1918-1939. Kraków: Wydawnictwo Literackie.

Obrębski, J. (2007). Studia etnosocjologiczne: T. 1. Polesie (A. Engelking, Red.). Warszawa: Oficyna Naukowa.

Plan parcelacyjny na Polesiu na rok 1939. (1938, luty 19). Dziennik Brzeski.

Prymaka-Oniszk, A. (2016). Bieżeństwo 1915: Zapomniani uchodźcy. Wołowiec: Czarne.

Śleszyński, W. (Red.). (z Jodzio, A.). (2009). Polesie w polityce rządów I/ Rzeczpospolitej. Białystok: Avalon.

Tołpa, S. (1936). Śladami łosia: Z wędrówek po Polesiu. Lwów: Zakład Narodowy im. Ossolińskich.

Weinfeld, I., Szturm de Sztrem, E., \& Piekałkiewicz, J. (1925). Atlas statystyczny Polski (Z. 2). Bydgoszcz: Instytut Wydawniczy "Bibljoteka Polska”.

Wierzbicki, M. (2000). Polacy i Białorusini w zaborze sowieckim. Warszawa: Volumen.

Wysłouch, S. (2013). Stosunki narodowościowe na terenie województw wschodnich [Wilno 1939/1940]. Warszawa: Studium Europy Wschodniej.

Бежанства 1915 года. (2000). Беласток: Ніва. 
Ласкович, В. П., \& Ласкович, В. В. (2002). Подвиг Коммунистической партии Западной Белоруссии (КПЗБ) 1919-1939 гг.: Исторический очерк. Брест.

Пущук, І. (2006). Берестейщина у міжвоєнний час: 1919-1939 рр. Луцьк: VАT. Волинська обласна друкарня.

Смалянчук, А. (2013). Палеская вёска ў стасунку да пана. W A. Смалянчук, Беларуская гісторыя: Знайсці чалавека (ss. 138-154). Мінск: Логвінаў.

\section{BIBLIOGRAPHY (TRANSLITERATION)}

Bezhanstva 1915 hoda. (2000). Belastok: Niva.

Cichoracki, P. (2016). Komuniści na Polesiu w latach 1921-1939. Łomianki: LTW.

Landau, Z., \& Tomaszewski, J. (1982). Gospodarka Polski międzywojennej: Vol. 3. 19301935. Warszawa: PWN.

Laskovich, V. P., \& Laskovich, V. V. (2002). Podvig Kommunisticheskoĭ partii Zapadnoĭ Belorussii (KPZB) 1919-1939 gg.: Istoricheskil ocherk. Brest.

Maty Rocznik Statystyczny 1938. (1938). Warszawa: Główny Urząd Statystyczny.

Mały Rocznik Statystyczny 1939. (1939). Warszawa: Gtówny Urząd Statystyczny.

Mędrzecki, W. (2018). Kresowy kalejdoskop: Wędrówki przez ziemie wschodnie Drugiej Rzeczypospolitej 1918-1939. Kraków: Wydawnictwo Literackie.

Obrębski, J. (2007). Studia etnosocjologiczne: Vol. 1. Polesie (A. Engelking, Ed.). Warszawa: Oficyna Naukowa.

Plan parcelacyjny na Polesiu na rok 1939. (1938, February 19). Dziennik Brzeski.

Prymaka-Oniszk, A. (2016). Bieżeństwo 1915: Zapomniani uchodźcy. Wołowiec: Czarne.

Pushchuk, I. (2006). Beresteǐshchyna u mizhvoiennyı chas: 1919-1939 rr. Luts'k: VAT. Volyns'ka oblasna drukarnia.

Smalianchuk, A. (2013). Paleskaia vioska ŭ stasunku da pana. In A. Smalianchuk, Belaruskaia historyia: Znaǐstsi chalaveka (pp. 138-154). Minsk: Lohvinaŭ.

Śleszyński, W. (Ed.). (with Jodzio, A.). (2009). Polesie w polityce rządów I/ Rzeczpospolitej. Białystok: Avalon.

Tołpa, S. (1936). Śladami łosia: Z wędrówek po Polesiu. Lwów: Zakład Narodowy im. Ossolińskich.

Weinfeld, I., Szturm de Sztrem, E., \& Piekałkiewicz, J. (1925). Atlas statystyczny Polski (Pt. 2). Bydgoszcz: Instytut Wydawniczy "Bibljoteka Polska”.

Wierzbicki, M. (2000). Polacy i Białorusini w zaborze sowieckim. Warszawa: Volumen.

Wysłouch, S. (2013). Stosunki narodowościowe na terenie województw wschodnich [Wilno 1939/1940]. Warszawa: Studium Europy Wschodniej. 